\title{
Effect of Poly(Methyl Vinyl Ether-co- maleic Anhydride) Copolymer on Bond Strength of Experimental Dental Adhesive
}

\author{
Poli(Metil Vinil Eter-ko-maleik Anhidrit) Kopolimerinin Deneysel \\ Dental Adezivin Bağ Dayanımına Etkisi
}

\author{
(1) Özge Çeliksöz ${ }^{1}$, (1) Özgür Irmak ${ }^{1}$, (1) Zeynep Dikmen², (1) Batu Can Yaman ${ }^{1}$, (1) Vural Bütün², (1) Füsun Özer \\ ${ }^{1}$ Eskişehir Osmangazi University Faculty of Dentistry, Restorative Dentistry, Eskişehir, Turkey \\ ${ }^{2}$ Eskişehir Osmangazi University Faculty of Science, Polymer Science and Technology, Eskişehir, Turkey \\ ${ }^{3}$ University of Pennsylvania School of Dental Medicine, Preventive and Restorative Sciences, Philadelphia, PA, USA
}

Keywords

Adhesive, bond strength, experimental adhesive, micro-tensile, PVM/MA

Anahtar Kelimeler

Adeziv, bağ dayanımı, deneysel adeziv, mikro-gerilim, PVM/MA

Received/Geliş Tarihi : 18.06 .2018

Accepted/Kabul Tarihi : 30.10.2018

doi:10.4274/meandros.galenos.2018.28190

Address for Correspondence/Yazışma Adresi: Özge Çeliksöz DDS,

Eskişehir Osmangazi University Faculty of Dentistry, Restorative Dentistry, Eskişehir, Turkey

Phone : +90 5069647505

E-mail : ozgee_ozdil@hotmail.com

ORCID ID: orcid.org/0000-0003-3095-6815

(C) Meandros Medical and Dental Journal, Published by Galenos Publishing House.

This is article distributed under the terms of the

Creative Commons Attribution NonCommercial 4.0

International Licence (CC BY-NC 4.0).

\begin{abstract}
Objective: The contents of adhesive systems directly affect their bond strength. The purpose of this in vitro study was to evaluate the bond strength of experimental two-step self-etch (SE) adhesive containing Poly(methyl vinyl ether-co-maleic anhydride) (PVM/MA) Copolymer (Gantrez S-97 HSU Solution, USA) and to compare its bond strength with those of commercially available SE adhesives and experimental two-step SE adhesive free of PVM/MA copolymer.

Materials and Methods: Fifty extracted human molar teeth were randomly divided into 5 equal group as follows ( $n=10)$; Clearfil SE Bond (SEB) (Kuraray Co., Osaka, Japan), Clearfil Protect Bond (PrB) (Kuraray Co., Osaka, Japan), Clearfil Universal Bond (UniB) (Kuraray Co., Osaka, Japan), experimental adhesive (ExpA), ExpA containing PVM/MA (ExpA-G). After application of the adhesives to dentin, resin composites were bonded. Specimens were stored in distilled water for $24 \mathrm{~h}$, and sectioned into beams followed by subjection to microtensile bond forces. Data were analyzed with ANOVA followed by Holm-Sidak multiple comparison test $(\alpha=0.05)$. Results: ANOVA results revealed a significant difference between the mean bond strength values of the adhesives $(p<0.0001)$. Multiple comparisons showed that mean bond strengths of all of the adhesives were significantly different from each other $(p<0.05)$. Highest bond strength was obtained in commercially available two-step SE adhesive, SEB $(15.93 \pm 6.84 \mathrm{MPa})$; while the lowest bond strength was obtained in the ExpA containing PVM/MA, ExpA-G $(6.08 \pm 2.85 \mathrm{MPa})$. The ExpA containing PVM/MA (ExpA-G) showed lower bonds strength values than the ExpA without PVM/MA (ExpA) $(p<0.05)$.

Conclusion: Addition of PVM/MA into the experimental two-step self-etch adhesive led to lower bond strengths.
\end{abstract}

Öz

Amaç: Adeziv sistemlerin içeriği bağlanma dayanımını doğrudan etkiler. Bu çalışmanın amacı, deneysel olarak hazırlanan iki aşamalı kendinden asitli dental adeziv materyale Poly (methyl vinyl ether-co-maleic anhydride) Copolymer (Gantrez S-97 HSU Solution, USA) kopolimerinin ilavesinin dentin bağ dayanımına etkisinin, piyasada bulunan kendinden asitli diğer bağlayıcı ajanlarla karşılaşııııımasıdır. 
Gereç ve Yöntemler: Deneysel olarak hazırlanan dental adeziv içeriğine \%10 oranında PVM/MA ilave edildi. Elli adet çekilmiş insan dişi rastgele 5 eşit gruba ayrıldı $(n=10)$. Deney grupları şu şekildedir: Clearfil SE Bond (SEB) (Kuraray, Osaka, Japan), Clearfil Protect Bond (PrB) (Kuraray, Osaka, Japan), Clearfil Universal Bond (UniB) (Kuraray, Osaka, Japan), deneysel adeziv (ExpA), PVM/MA kopolimeri eklenmiş deneysel adeziv (ExpA-G). Restorasyonu tamamlanan dişler 24 saat distile suda bekletildikten sonra kestiler alınarak mikrogerilim bağ dayanımı testi uygulandı. Veriler tek yönlü varyans analizi ve Holm-Sidak çoklu karşılaştırma testiyle analiz edildi $(\alpha=0,05)$.

Bulgular: Varyans analizi sonuçları test edilen adezivlerin ortalama $\mu \mathrm{GBD}$ değerleri arasında istatistiksel olarak belirgin bir fark olduğunu ortaya koydu $(p<0,0001)$. Çoklu karşılaştırma sonuçları ise tüm grupların ortalama $\mu G B D$ değerlerinin istatistiksel olarak birbirlerinden farklı olduğunu gösterdi $(p<0,05)$. En yüksek $\mu$ GBD iki aşamalı SE adeziv olan SEB grubunda $[15,93 \pm 6,84$ megapascal (MPa)] gözlenirken, en düşük değer iki aşamalı SE deneysel adeziv olan ExpA-G grubunda $(6,08 \pm 2,85 \mathrm{MPa})$ tespit edildi. PVM/ MA içeren ExpA-G $(6,08 \pm 2,85 \mathrm{MPa})$ grubunun $\mu \mathrm{GBD}$ değerleri, PVM/MA içermeyen deneysel adeviz olan ExpA $(9,46 \pm 2,68 \mathrm{MPa})$ grubundan anlamlı olarak düşük bulundu $(p<0,05)$.

Sonuç: Deneysel adezive PVM/MA kopolimeri ilavesi bağlanma dayanımını olumsuz yönde etkilemiştir.

\section{Introduction}

Despite the advancements in dental adhesive and restorative systems, polymerization contraction of composite resins and resulting micro-gaps at the tooth-restoration interface is still a major problem in restorative dentistry. Cariogenic bacteria may leak through these gaps and lead to secondary caries (1$3)$. Another cause of formation of secondary caries is residual caries and bacteria (4). Even if a leakproof restoration is built; residual bacteria can live more than 1 year and grow (5). Secondary caries is one of the main reasons for the need of replacing the composite restorations $(6,7)$. Therefore, besides providing a good seal, it is necessary to reduce the amount of residual bacteria for a long-lasting restoration. In this manner, the most essential and promising strategy is to add antibacterial agents to resin composites or adhesives.

The first adhesive system in which an antibacterial group added was Clearfil Protect Bond (PrB) (Kuraray Co., Osaka, Japan). It is a two-step selfetch (SE) adhesive system containing antibacterial methacryloyloxydodecyl pyridinium bromide (MDPB) monomer, in the acidic primer of the system (8). This MDPB containing adhesive has antibacterial effect in case of contact, even if it does not release any antibacterial agent when polymerized (9-12).

Poly(methyl vinyl ether-co-maleic anhydride) (PVM/MA) is a biodegradable polyanhydride which is known as 'Gantrez' in the market and is used widely for pharmaceutical purposes. This molecule is a suitable copolymer for the preparation of dosage forms with nanoparticles having bioadhesive or mucoadhesive properties (13). It can be used for treatment of toothache, bacterial and fungal infections, aphthous ulcers, lichen planus, inflammation and stomatitis, which occur in the mouth cavity (14). The PVM/MA copolymer has the effect of reducing the adhesion of bacteria to the enamel surface. This effect may be attributed to the prevention of calcium accumulation on the enamel surface of the carboxylate side chains that chelate calcium ions (15). There is a commercial toothpaste (Colgate Total, Colgate-Palmolive Company) containing a combination of triclosan, PVM/MA and fluoride. PVM/MA enhances the effect of triclosan and its antibacterial properties and allows it to stay longer on the tooth surface (16). A mouthwash containing 3\% triclosan and 0.25\% PVM/ MA has been shown to significantly reduce dental plaque when used before or after brushing (17).

Taking advantage of antibacterial properties by adding PVM/MA copolymer into a dental adhesive system could be promising. Therefore, it is essential to know the bonding performance of the adhesive systems with antibacterial agent. In this study, it was aimed to evaluate the bond strength of an experimental SE adhesive system containing antibacterial agent, PVM/MA copolymer. The first null hypothesis tested was that the bond strength of experimental adhesive would not be different from the bond strength values of the commercial adhesives tested. The second null hypothesis was that addition of PVM/MA to the experimental adhesive would not affect the bond strength of the experimental adhesive.

\section{Materials and Methods}

In this study, 50 extracted human molar teeth were used. Teeth were stored at room temperature in distilled water until the time of experiment. Teeth were embedded in acrylic blocks $2 \mathrm{~mm}$ below the cementoenamel junction. Occlusal surfaces of the teeth were cut horizontally at low speed under water cooling with diamond cutting disc (Isomet, Buehler 


\begin{tabular}{|l|l|l|}
\hline \multicolumn{3}{|l|}{ Table 1. Grouping of samples } \\
\hline Group & Adhesive system & Composite \\
\hline Group 1 (SEB) & Clearfil SE Bond & $\mathrm{Z} 550$ \\
\hline Group 2 (PrB) & Clearfil Protect Bond & $\mathrm{Z} 550$ \\
\hline Group 3 (UniB) & Clearfil Universal Bond & $\mathrm{Z} 550$ \\
\hline Group 4 (ExpA) & Experimental Adhesive & $\mathrm{Z} 550$ \\
\hline Group 5 (ExpA-G) & $\begin{array}{l}\text { Experimental Adhesive } \\
\text { with PVM/MA }\end{array}$ & $\mathrm{Z} 550$ \\
\hline $\begin{array}{l}\text { SEB: SE Bond, PrB: Protect Bond, UniB: Universal Bond, ExpA: } \\
\text { Experimental Adhesive, ExpA-G: Experimental Adhesive with } \\
\text { polymethyl vinyl ether-co-maleic anhydride, PVM/MA: Polymethyl } \\
\text { vinyl ether-co-maleic anhydride, SE: Self-etch }\end{array}$ \\
\hline
\end{tabular}

Ltd., Lake Bluff, IL, USA) to obtain deep dentine tissue. Exposed dentin surfaces were polished with 600 grit silicon carbide paper under running water for 30 seconds to obtain a uniform smear layer.

The study were approved by the Eskişehir Osmangazi University of Local Ethics Committee (date: 18.04.2016, no: 13).

\section{Grouping of Samples and Restorative Procedures}

Teeth were randomly and equally divided into 5 groups according to the adhesive systems $(n=10)$ (Table 1).

After application of the commercial adhesive systems [SE Bond (SEB), PrB and Universal Bond (UniB)]

\begin{tabular}{|c|c|c|c|c|}
\hline Material & Type & Content & $\begin{array}{l}\text { Lot } \\
\text { number }\end{array}$ & Manufacturer \\
\hline Clearfil SE Bond & $\begin{array}{l}\text { Two step self-etch } \\
\text { adhesive }\end{array}$ & $\begin{array}{l}\text { Primer: 10-methacryloyloxydodecyl dihydrogen phosphate, } \\
\text { 2-hydroxyethyl methacrylate, hydrophilic aliphatic } \\
\text { dimethacrylate, dl-camphorquinone, N, N-diethanol-p- } \\
\text { tolidine, water } \\
\text { Bond: } 10 \text {-methacryloyloxydodecyl dihydrogen phosphate, } \\
\text { bisphenol A diglycidyl methacrylate, 2-hydroxyethyl } \\
\text { methacrylate } \\
\text { hydrophobic aliphatic dimethacrylate, dl-camphorquinone, } \\
\mathrm{N}, \mathrm{N} \text {-diethanol-p-tolidine, colloidal silica }\end{array}$ & 000181 & $\begin{array}{l}\text { Kuraray Co., } \\
\text { Osaka, Japan }\end{array}$ \\
\hline $\begin{array}{l}\text { Clearfil SE Protect } \\
\text { Bond }\end{array}$ & $\begin{array}{l}\text { Two step self-etch } \\
\text { adhesive }\end{array}$ & $\begin{array}{l}\text { Primer: 10-methacryloyloxydodecyl dihydrogen phosphate, } \\
\text { 12-methacryloyloxydodecylpyridinium bromide, } \\
\text { 2-hydroxyethyl methacrylate hydrophilic dimethacrylate, } \\
\text { water } \\
\text { Bond: } 10 \text {-methacryloyloxydodecyl dihydrogen phosphate, } \\
\text { bisphenol A diglycidyl methacrylate, 2-hydroxyethyl } \\
\text { methacrylate hydrophobic aliphatic dimethacrylate, } \\
\text { dl-camphorquinone, N, N-diethanol-p-tolidine, colloidal } \\
\text { silica, sodium fluoride }\end{array}$ & 000015 & $\begin{array}{l}\text { Kuraray Co., } \\
\text { Osaka, Japan }\end{array}$ \\
\hline $\begin{array}{l}\text { Clearfil Universal } \\
\text { Bond }\end{array}$ & $\begin{array}{l}\text { One step self-etch } \\
\text { universal adhesive }\end{array}$ & $\begin{array}{l}\text { 10-methacryloyloxydodecyl dihydrogen phosphate, } \\
\text { bisphenol A diglycidyl methacrylate, 2-hydroxyethyl } \\
\text { methacrylate, hydrophilic aliphatic dimethacrylate, } \\
\text { dl-camphorquinone, colloidal silica, silane coupling agent, } \\
\text { ethanol, water }\end{array}$ & 000019 & $\begin{array}{l}\text { Kuraray Co., } \\
\text { Osaka, Japan }\end{array}$ \\
\hline $\begin{array}{l}\text { Experimental } \\
\text { Adhesive }\end{array}$ & $\begin{array}{l}\text { Two step self-etch } \\
\text { adhesive }\end{array}$ & $\begin{array}{l}\text { Primer: } 40 \% \text { 2-methacryloyloxy ethyl phosphate, ethanol } \\
\text { Bond: HEMA, triethylene glycol dimethacrylate, bisphenol } \\
\text { A glycerolate dimethacrylate, dimethylaminoethyl } \\
\text { methacrylate, camphorquinone }\end{array}$ & - & - \\
\hline $\begin{array}{l}\text { Experimental } \\
\text { adhesive } \\
\text { with Polymethyl } \\
\text { vinyl ether-co- } \\
\text { maleic anhydride }\end{array}$ & $\begin{array}{l}\text { Two step self-etch } \\
\text { adhesive }\end{array}$ & $\begin{array}{l}\text { Primer: } 40 \% \text { 2-methacryloyloxy ethyl phosphate, ethanol } \\
\text { Bond: HEMA, triethylene glycol dimethacrylate, bisphenol } \\
\text { A glycerolate dimethacrylate, dimethylaminoethyl } \\
\text { methacrylate, camphorquinone, polymethyl vinyl ether-co- } \\
\text { maleic anhydride }\end{array}$ & - & - \\
\hline Z550 & $\begin{array}{l}\text { Nano hybrid } \\
\text { universal } \\
\text { composite resin }\end{array}$ & - & N728631 & $\begin{array}{l}\text { 3M/ESPE, St. } \\
\text { Paul, MN, } \\
\text { U.S.A }\end{array}$ \\
\hline
\end{tabular}


according to the manufacturer's instructions, resin composite build-ups (Z550, 3M Espe, St. Paul, Mn, U.S.A.) were constructed in double $2 \mathrm{~mm}$ increments, with each increment being light-cured for $20 \mathrm{~s}$. A light emitting diode curing device (Starlight $\mathrm{S}$, Mectron, SPA, Loreto, Italy) with a light intensity of $800 \mathrm{~mW} /$ $\mathrm{cm}^{2}$ was used for polymerization of the adhesives and resin composites. All adhesive systems and restorative procedures were performed by a single operator. The contents of adhesives and restorative materials used in the study are given in Table 2.

\section{Preparation of Experimental Adhesive}

Two different two-step SE experimental adhesive systems were used in this study. Only difference between these adhesive systems were that one of the experimental adhesive system contained PVM/MA in its adhesive bottle.

\section{2- Methacryloyloxy Ethyl Phosphate (Methacryloyloxyethyl Dihydrogen Phosphate) Synthesis}

Eighteen $\mathrm{mL}(0.148 \mathrm{~mol})$ of 2-hydroxyethyl methacrylate (HEMA), $0.01 \mathrm{~g}$ of hydroquinone monomethyl ether inhibitor was dissolved in 175 $\mathrm{mL}$ diethyl ether with a magnetic stirrer in a threeneck round-bottom flask in an inert gas atmosphere. Twenty-two $\mathrm{mL}$ of triethyl amine $(0.157 \mathrm{~mol})$ was then added to remove the $\mathrm{HCl}$ acid which would form in the medium as a salt. A mixture of $13.82 \mathrm{~mL}$ of $\mathrm{POCl}_{3}$ (0.148 mol) (nHEMA/nPOCl $: 1: 1$ ) and $50 \mathrm{~mL}$ of diethyl ether at $-40{ }^{\circ} \mathrm{C}$ was slowly added to the medium using a dropping funnel. When the addition of the $\mathrm{POCl}_{3}$ solution was completed, flask was kept at room temperature nightlong. After stirring nightlong at room temperature, the triethylamine hydrochloride salt was removed from the medium by filtration. The organic phases were washed twice with $150 \mathrm{~mL}$ of saturated sodium chloride solution adjusted to a $\mathrm{pH}$ of about 1 with $1 \mathrm{~N}$ hydrochloric acid $(\mathrm{HCl})$ and then the mixture was washed twice with an aqueous solution of which by weight $10 \%$ is $150 \mathrm{~mL}$ of $\mathrm{NaHCO}_{3}$. By extraction method, the aqueous phase and the diethyl ether phase were separated. The diethyl ether phase contains organic structures, while the aqueous phase contains salt forms of unreacted reactants. After drying the diethyl ether phase with anhydrous sodium sulphate, the solvent was evaporated under vacuum by means of an evaporator to a constant weight to yield $5 \mathrm{~mL}$ of light yellow-colored liquid (Figure 1) (18).
${ }^{1} \mathrm{H}$ nuclear magnetic resonance (NMR) spectrum of the output molecule and the synthesized molecule in $\mathrm{CDCl}_{3}$ are exhibited. In the after-synthesis NMR spectrum, protons of $-\mathrm{OH}$ groups due to phosphonic acid were observed at $\delta=10 \mathrm{ppm}$. Besides, the $-\mathrm{OH}$ group of the output molecule at $\delta=3$ ppm disappeared. An upward chemical shift was observed in the $\mathrm{CH}_{2}$ groups observed at $\delta=3.75 \mathrm{ppm}$ bound to the $\mathrm{OH}$ group and the $\mathrm{CH}_{2}$ groups observed at $\delta=4.15 \mathrm{ppm}$ at the $\beta$ position, and peaks at $\sim 4.25$ ppm were observed to coincide (Figure 2, 3).

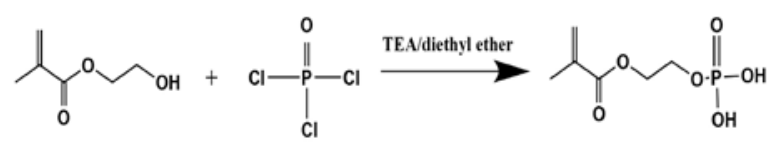

HEMA

MMEP

Figure 1. 2-methacryloyloxy ethyl phosphate synthesis scheme HEMA: Hydroxyethyl methacrylate, MMEP: Methacryloyloxy ethyl phosphate

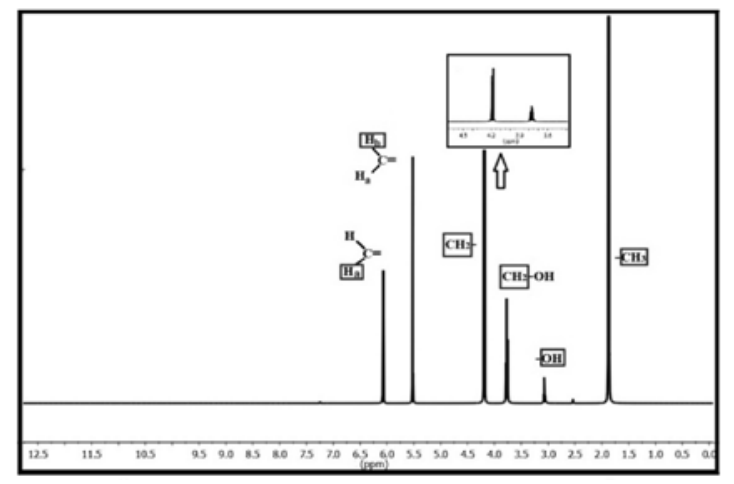

Figure 2. ${ }^{1} \mathrm{H}$ nuclear magnetic resonance spectrum $\left(\mathrm{CDCl}_{3}\right)$ of 2-hydroxyethyl methacrylate output material

$\mathrm{CDCl}_{3}$ : Deuterated chloroform

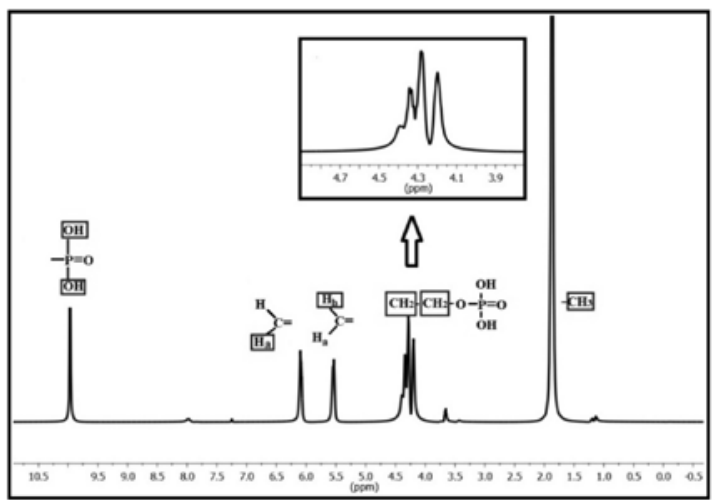

Figure 3. The synthesized 2- (phosphonoxy) ethyl methacrylate molecule ${ }^{1} \mathrm{H}$ nuclear magnetic resonance spectrum $\left(\mathrm{CDCl}_{3}\right)$

$\mathrm{CDCl}_{3}$ : Deuterated chloroform 


\section{Preparation of the Experimental Primer Mixture}

The primer mixture was obtained by dissolving the freshly synthesized methacryloyloxy ethyl phosphate (MMEP) monomer in ethanol in 10\%, 20\%, 30\%, 40\% proportions, and used as the selt-etching agrnt. In these samples prepared at different concentrations, the solutions prepared at $10 \%, 20 \%, 30 \%$, could not be used because their demineralizing effects were not sufficient as complete premature failures of the specimens occurred during the sample preparation for the bond strength test.

\section{Preparation of Experimental Bond Mixture}

A total of $10 \mathrm{~g}$ of adhesive material was prepared using 30\% HEMA ( $3 \mathrm{~g}), 10 \%$ ( $1 \mathrm{~g})$, triethylene glycol dimethacrylate and $60 \%(6 \mathrm{~g})$ bisphenol a glycerolate dimethacrylate (BISGMA). $0.1 \mathrm{~g}$ dimethylaminoethyl methacrylate ( $1 \%$ of the total mass) was added as an accelerator. $40 \mathrm{mg}$ camphorquinone (CQ) $(0.4 \%$ of the total mass) was added as photoinitiator. Mixture was mixed at $1200 \mathrm{rpm}$ for an hour.

Adding PVM/MA into the Experimental Adhesive

2 g PVM/MA (Gantrez S-97 HSU Solution) (10\% of total mass) was added to the bonding agent.

Application of Experimental Adhesive Systems

Acidic primer (first bottle) of the experimental adhesive system without PMV/MA was applied to the dentin surface by rubbing for $40 \mathrm{sl}$ followed by $5 \mathrm{~s}$ airdrying. Adhesive (second bottle) was then applied to the dentin surface for $10 \mathrm{~s}$ and was light-cured for 40 $\mathrm{s}$ (Starlight S, Mectron Dental). Experimental adhesive material containing PMV/MA was applied exactly the same was described.

\section{Micro Tensile Bond Strength Test}

After completing of the adhesive protocols, two 2 $\mathrm{mm}$ thick resin composite increments were bonded to the dentin surfaces. Each increment was light cured for $20 \mathrm{~s}$. Restored specimens were kept in distilled water at $37^{\circ} \mathrm{C}$ for $24 \mathrm{~h}$. The samples were then cut along the long axis with a cutting device (Isomet, Buehler Ltd., Lake Bluff, IL, USA) at $300 \mathrm{rpm}$ under water cooling to obtain test sticks of $1.00 \mathrm{~mm}^{2}$ bonded cross-sectional surface area. Each obtained sample was glued to the test apparatus the microtensile test device (MOD Dental MIC-101, Esetron Smart Robotechnologies, Ankara, Turkey) with a cyanoacrylate adhesive, and was subjected to tensile force at a cross-head speed of $0.5 \mathrm{~mm} / \mathrm{min}$. The tensile force of each sample was measured in Newtons. The bond strength of each sample was then recorded in megapascals, obtained by dividing the fracture force by the cross-sectional surface area.

\section{Statistical Analysis}

The fitness of the obtained data to the normal distribution was examined by D'Agostino \& Pearson omnibus normality test. One-way analysis of variance and the Holm-Sidak multiple comparison tests were performed after the data were determined to be normally distributed. Statistical significance was set at 0.05. A commercial statistical analysis software (Prism 6.0, GraphPad Software, La Jolla, CA, USA) was used for the analysis.

\section{Results}

The variance analysis results showed a statistically significant difference between the mean micro tensile bond strength ( $\mu \mathrm{TBS}$ ) values of the tested adhesive systems $(p<0.0001)$. Multiple comparison results showed that the mean $\mu$ TBS values of all groups were statistically different $(p<0.05)$. Mean $\mu$ TBS values and standard deviations are given in Table 3 . The highest $\mu$ TBS was observed in the two-step SE adhesive system, SEB $(15.93 \pm 6.84 \mathrm{MPa})$, while the lowest value was observed in the two-step experimental SE adhesive system, Exp-G $(6.08 \pm 2.85 \mathrm{MPa})$. The mean $\mu \mathrm{TBS}$ of the experimental adhesive system containing PVM/MA, ExpA-G $(6.08 \pm 2.85 \mathrm{MPa})$, was significantly lower than that of the experimental adhesive system without PVM/MA, ExpA $(9.46 \pm 2.68 \mathrm{MPa})$ group $(p<0.05)$.

\begin{tabular}{|c|c|}
\hline Groups & $\begin{array}{l}\text { Mean } \pm \text { standard deviation } \\
(\mathrm{MPa})^{*}\end{array}$ \\
\hline SEB & $15.93 \pm 6.84^{\mathrm{a}}$ \\
\hline PrB & $13.45 \pm 4.22^{b}$ \\
\hline UniB & $12.56 \pm 4.47^{c}$ \\
\hline ExpA & $9.46 \pm 2.68^{d}$ \\
\hline ExpA-G & $6.08 \pm 2.85^{e}$ \\
\hline \multicolumn{2}{|c|}{$\begin{array}{l}\text { SEB: SE Bond, PrB: Protect Bond, UniB: Universal Bond, ExpA: } \\
\text { Experimental Adhesive, ExpA-G: Experimental Adhesive with } \\
\text { polymethyl vinyl ether-co-maleic anhydride, SE: Self-etch } \\
{ }^{*} \text { Different letters indicate statistical differences between groups } \\
(p<0.05)\end{array}$} \\
\hline
\end{tabular}




\section{Discussion}

In this study; bond strengths of experimental twostep SE adhesive systems with or without the addition of antibacterial PVM/MA copolymer were with that of 3 commercial adhesives were compared. As the bond strength of experimental adhesive systems was found to be significantly lower than that of commercial adhesives, the first null hypothesis that the bond strength of experimental adhesive systems would be similar to that of commercial adhesive systems was rejected. Furthermore, the addition of PVM/MA to experimental adhesive system significantly reduced the bond strength of the experimental adhesive system; therefore, the second hypothesis of the study was rejected.

Polymerizable phosphate monomers are widely used in the production of SE adhesive systems. These hydrophilic phosphate monomers are dissolved in solvents like pure water, ethanol-water or acetonewater mixtures (19). The MMEP monomer is one of these acidic phosphates and is present in the content of some commercial SE adhesive systems $(19,20)$. In this study, we synthesized and added MMEP monomer in the experimental adhesive systems. Micro-shear bond strength of with MMEP containing adhesive system (Self \& Etch Bond, Vigodent) was found to be very low compared to MDP containing two-step SE adhesive system (Clearfil SE Bond, Kuraray Co., Osaka, Japan) (21). Mentioned study was conducted in human enamel, so, it is impossible to know how this monomer will perform in the dentin. It was reported that the MDP monomer is more stable than the MMEP monomer (19). In our study, primer mixture of the experimental adhesive systems was obtained by dissolving synthesized MMEP in ethanol at $10 \%, 20 \%, 30 \%, 40 \%$ concentrations. All the samples bonded with the experimental adhesive systems having MMEP concentration below 40\% in the primer solution, showed premature failures during sample sectiononing fort the $\mu$ TBS test. This could indicate lower demineralization potential of MMEP at lower concentrations than $40 \%$ on human dentin. Correspondingly, the $\mu$ TBS of the experimental adhesives synthesized in this study were lower compared to the commercial adhesives; Clearfil SE Bond, Clearfil PrB and Clearfil UniB.
The addition of the PVM/MA copolymer into the adhesive bottle of the SE experimental adhesive system negatively affected the $\mu$ TBS to dentin. Two studies have investigated the effect of PVM/MA copolymer on dental adhesives. In the first study, 50 $\mathrm{mg} / \mathrm{mL}$ PVM/MA copolymer (Gantrez S97 BF form) in powder was added to the primer and adhesive bottles of Clearfil SE Bond and to Prime \& Bond NT, and 24 $h$ fracture toughness tests were performed on the extracted human teeth. According to the results of the study, the addition of PVM/MA copolymer to the primer of Clearfil SE Bond or to the adhesive did not change the bonding values statistically. However, the addition of PVM/MA to Prime \& Bond NT, which is a total etch (TE) adhesive system, has greatly reduced the bonding strenght (22). The researchers noted that PVM/MA copolymer did not completely dissolve in the acetone-based Prime \& Bond NT and formed microscopic clusters in the mixture. The reason for this might be that PVM/MA possesses carboxylic acid and anhydride side chains which may be more easily soluble in ethanol and water than in acetone. In the second study, $50 \mathrm{mg} / \mathrm{mL}$ PVM/MA copolymer (Gantrez S97 BF form) in powder form was added to the 2-step SE adhesive systems Clearfil SE Bond, Fluorobond II and TE adhesive system Adper Single Bond Plus. Twenty-four h micro-shear bond strength results indicated stated that the PVM/MA copolymer positively affected the bonding performance of Clearfil SE Bond and Adper Single Bond Plus, while Fluorobond II were not effected by the addition of PVM/MA (23). In the two studies mentioned above and in the present study, quite different methods were followed. While, in previos studies, PVM/ MA in powder form was added to the commercially available adhesive systems; in the present study, liquid PVM/MA was added into the experimental adhesive during the production phase. PVM/MA copolymer has anhydride functional groups which are very reactive and can easily react with various mono and bifunctional reagents. These reactive anhydride structures can be easiliy degraded with water hydrolytically or with protic solvents. For example, reaction of water with anhydride groups results in a carboxylic acid containing polymeric structure. These groups confer weak acid quality to the polymer. The -OH end groups and carboxylic acid groups increase the ability of polymers to form hydrogen bonds with 
$-\mathrm{OH},-\mathrm{NH}$ functional compounds such as water and alcohols. If bifunctional crosslinkers such as diamines and diols are used, PVM/MA chains can be crosslinked by amidation and esterification reactions, respectively. In addition, after converting anhydride groups to carboxylic acid groups, the carboxylic ends can be crosslinked via ring opening and esterification reactions with bis-epoxy compounds (24). Because of the sensitive properties mentioned above, the use of the PVM/MA copolymer during production may allow chemical bonding to the adhesive component, preventing possible side reactions with components such as moisture in the air.

\section{Conclusion}

The adddition of PVM/MA comploymer in experimental adhesive system with MMEP monomer negatively influenced the $\mu$ TBS to dentin. MMEP containing experimental two-step SE systems showed lower bond strengths than that of the commercially available two-step and one-step SE adhesive systems. Further studies investigating the effect of PVM/MA on long-term bond strength of SE adhesives are needed.

\section{Ethics}

Ethics Committee Approval: The study were approved by the Eskişehir Osmangazi University of Local Ethics Committee (date: 18.04.2016, no: 13).

Informed Consent: Consent form was filled out by all participants.

Peer-review: Externally peer-reviewed.

\section{Authorship Contributions}

Concept: F.Ö., Ö.I., V.B., Z.D., Design: Ö.I., V.B., Z.D., Data Collection or Processing: Ö.Ç., Ö.I., Analysis or Interpretation: Ö.I., Ö.Ç., B.C.Y., Literature Search: Ö.I., Ö.Ç., Z.D., Writing: Ö.I., Ö.Ç., Z.D.

Conflict of Interest: No conflict of interest was declared by the authors.

Financial Disclosure: The authors declared that this study received no financial support.

\section{References}

1. De Munck J, Van Landuyt K, Peumans M, Poitevin A, Lambrechts $\mathrm{P}$, Braem $\mathrm{M}$, et al. A critical review of the durability of adhesion to tooth tissue: methods and results. J Dent Res 2005; 84: 11832.

2. Loguercio AD, Reis A, Bortoli G, Patzlaft R, Kenshima S, Rodrigues Filho LE, et al. Influence of adhesive systems on interfacial dentin gap formation in vitro. Oper Dent 2006; 31: 431-41.
3. Hashimoto $M$, Ohno $H$, Kaga $M$, Endo $K$, Sano $H$, Oguchi $H$. In vivo degradation of resin-dentin bonds in humans over 1 to 3 years. J Dent Res 2000; 79: 1385-91.

4. Li F, Weir MD, Chen J, Xu HH. Effect of charge density of bonding agent containing a new quaternary ammonium methacrylate on antibacterial and bonding properties. Dent Mater 2014; 30: 43341.

5. Brännström $\mathrm{M}$. The cause of postrestorative sensitivity and its prevention. J Endod 1986; 12: 475-81.

6. Arora $\mathrm{R}, \mathrm{Rao} \mathrm{MH}$. Comparative evaluation of the antibacterial effects of four dentine bonding systems: An in vitro study. J Conserv Dent 2013; 16: 466-70.

7. Chai $Z$, Li F, Fang $M$, Wang $Y$, Ma $S$, Xiao $Y$, et al. The bonding property and cytotoxicity of a dental adhesive incorporating a new antibacterial monomer. J Oral Rehabil 2011; 38: 849-56.

8. Imazato S, Kuramoto A, Takahashi Y, Ebisu S, Peters MC. In vitro antibacterial effects of the dentin primer of Clearfil Protect Bond. Dent Mater 2006; 22: 527-32.

9. Imazato S, Ehara A, Torii M, Ebisu S. Antibacterial activity of dentine primer containing MDPB after curing. J Dent 1998; 26: 267-71.

10. Imazato S, Imai T, Russell RR, Torii M, Ebisu S. Antibacterial activity of cured dental resin incorporating the antibacterial monomer MDPB and an adhesion-promoting monomer. J Biomed Mater Res 1998; 39: 511-5.

11. Imazato $\mathrm{S}$, Tarumi $\mathrm{H}$, Kato $\mathrm{S}$, Ebisu $\mathrm{S}$. Water sorption and colour stability of composites containing the antibacterial monomer MDPB. J Dent 1999; 27: 279-83.

12. Imazato $\mathrm{S}$, Chen JH, Ma S, Izutani N, Li F. Antibacterial resin monomers based on quaternary ammonium and their benefits in restorative dentistry. Jpn Dent Sci Rev 2012; 48: 115-25.

13. Arbós P, Wirth M, Arangoa MA, Gabor F, Irache JM. Gantrez AN as a new polymer for the preparation of ligand-nanoparticle conjugates. J Control Release 2002; 83: 321-30.

14. Salman HHA, Goñi Al. Nanoparticles comprising half esters of poly (methyl vinyl ether-co-maleic anhydride) and uses thereof. Google Patents; 2012.

15. McConnell MD, Liu Y, Nowak AP, Pilch S, Masters JG, Composto RJ. Bacterial plaque retention on oral hard materials: effect of surface roughness, surface composition, and physisorbed polycarboxylate. J Biomed Mater Res A 2010; 92: 1518-27.

16. DeSalva SJ, Kong BM, Lin YJ. Triclosan: a safety profile. Am J Dent 1989;2: 185-96.

17. Mandel ID. Antimicrobial mouthrinses: overview and update. J Am Dent Assoc 1994; 125: 2-10.

18. Jang J, Jeong YK. Synthesis and flame-retardancy of UV-curable methacryloyloxy ethyl phosphates. Fiber and Polym 2008; 9: 667-73.

19. Moszner N, Salz U, Zimmermann J. Chemical aspects of selfetching enamel-dentin adhesives: a systematic review. Dent Mater 2005; 21: 895-910.

20. Salz U, Zimmermann J, Zeuner F, Moszner N. Hydrolytic stability of self-etching adhesive systems. J Adhes Dent 2005; 7: 107-16. 
21. Torres CR, Barcellos DC, Pucci CR, Lima Gde M, Rodrigues CM, Siviero M. Influence of methods of application of self-etching adhesive systems on adhesive bond strength to enamel. J Adhes Dent 2009; 11: 279-86.

22. Kim CS, Ozer F, Mante FK. Fracture mechanics of dental adhesives supplemented with Polymethyl-vinyl-ether-co-maleic anhydride. J Adhes Sci Technol 2017; 31: 1116-24.
23. Ozer F, Park S, Yaman BC, Blatz MB. Effect of PVM/MA copolymer on bond durability of adhesive resins. $42^{\text {st }}$ Annual Meeting \& Exhibition of the AADR; Seattle, WA, USA. 2012.

24. Irache JM, Huici M, Konecny M, Espuelas S, Campanero MA, Arbos P. Bioadhesive properties of Gantrez nanoparticles. Molecules 2005; 10: 126-45. 